Article

\title{
A Novel Method for the Determination of Vancomycin in Serum by High-Performance Liquid Chromatography-Tandem Mass Spectrometry and Its Application in Patients with Diabetic Foot Infections
}

\author{
Min Liu ${ }^{1, *}$, Zhi-Hui Yang ${ }^{2}$ and Guo-Hui Li ${ }^{1, *}$ \\ 1 Department of Pharmacy, National Cancer Center/National Clinical Research Center for Cancer/Chinese \\ Academy of Medical Sciences and Peking Union Medical College, Beijing 100021, China \\ 2 Institute of Aviation Medicine of Air Force, Beijing 100142, China; zhyanghos@163.com \\ * Correspondence: liumin26081@cicams.ac.cn (M.L.); lgh0603@cicams.ac.cn (G.-H.L.); \\ Tel.: +86-010-8778-8040 (M.L.); +86-010-8778-8573 (G.-H.L.)
}

Received: 11 September 2018; Accepted: 6 November 2018; Published: 10 November 2018

check for updates

\begin{abstract}
A novel, precise, and accurate high-performance liquid chromatography-tandem mass spectrometry (Q-trap-MS) method was developed, optimized, and validated for determination of vancomycin in human serum using norvancomycin as an internal standard. Effect of different parameters on the analysis was evaluated. ZORBAX SB-C ${ }_{18}$ column $(150 \times 4.6 \mathrm{~mm}, 5 \mu \mathrm{m})$ using water (containing $0.1 \%$ formic acid, $v / v$ )-acetonitrile (containing $0.1 \%$ formic acid, $v / v$ ) as a mobile phase was chosen. The calibration curve was linear over the concentration ranges of 1 to $2000 \mathrm{ng} / \mathrm{mL}$ for vancomycin. The limit of detection (LOD) and limit of quantification (LOQ) for vancomycin were 0.3 and $1.0 \mathrm{ng} / \mathrm{mL}$. Recoveries were between 87.2 and $102.3 \%$, which gave satisfactory precision. A total of 100 serum samples (from 50 patients with diabetic foot proven Gram-positive infection and 50 nondiabetic patients with pneumonia requiring hospitalization and antibiotic therapy) were analyzed by this method. The trough vancomycin concentrations of diabetic foot infection (DFI) patients and nondiabetic patients were $8.20 \pm 2.83 \mu \mathrm{g} / \mathrm{mL}$ (range: $4.80-14.2 \mu \mathrm{g} / \mathrm{mL}$ ) and $15.80 \pm 5.43 \mu \mathrm{g} / \mathrm{mL}$ (range: $8.60-19.5 \mu \mathrm{g} / \mathrm{mL}$ ), respectively. The method is sensitive, precise, and reproducible, it could be applied for routine laboratory analysis of vancomycin in serum samples.
\end{abstract}

Keywords: vancomycin; norvancomycin; high performance liquid chromatography—tandem mass spectrometry; Diabetic Foot Infection (DFI); MRSA; Serum

\section{Introduction}

Diabetic foot infection (DFI) is a serious complication of diabetes, which can be caused by a variety of microorganisms. Among the common pathogens, Gram-positive cocci, especially Staphylococcus aureus, have often been reported to be related to DFIs [1-3]. Methicillin-resistant Staphylococcus aureus (MRSA) often occurs when patients are hospitalized or treated in community hospitals, it can be detected in approximately $20 \%$ DFIs patients, which can prolong healing time and cause a lot of serious problems. This deadly pathogen is not conducive to wound healing and increases the risk of lower limb amputation. Antibiotic therapy is necessary when treating with aerobic Gram-positive cocci (such as MRSA) [4]. Vancomycin, (Figure 1), a kind of glycopeptide antibiotic, is often recommended for severe skin/soft tissue infections caused by MRSA, such as DFIs and so on [5,6]. Hypoxia and ischemia of lower limbs occurs in most DFIs patients, which can reduce the tissue penetration of antibacterial agents and may significantly change the pharmacokinetics of antibiotics in serum and tissues [7]. Previous studies have revealed that vancomycin can penetrate into the interstitial fluid [8-10]. Although the 
vancomycin serum concentrations of these patients are similar, the level of tissue exposure varies greatly. Skhirtladze et al. [8] once compared skin penetration of vancomycin in different patients (with or without diabetes), the results showed that the plasma concentrations of vancomycin in diabetic patients and nondiabetic patients were similar, anyway, in this study, only six diabetic patients were included and there was no study showing that whether there was a difference of blood concentration of vancomycin between DFI patients and patients without DFI.

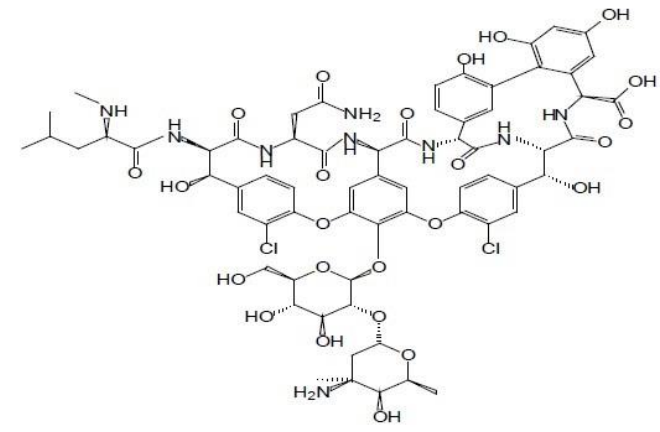

Vancomycin

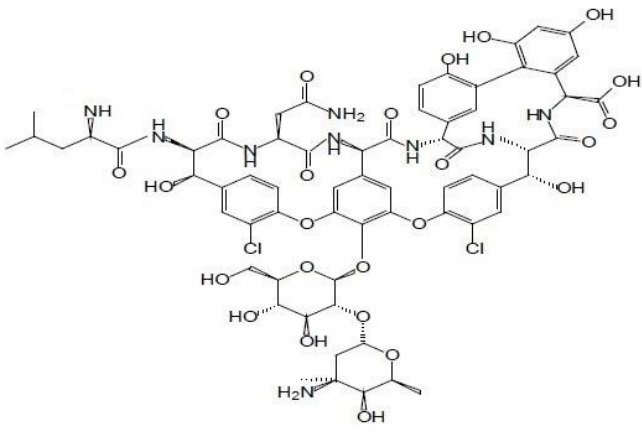

Norvancomycin

Figure 1. Structure of vancomycin and norvancomycin.

A lot of methods have been established for the determination of vancomycin, such as HPLC [11-13], capillary electrophoresis [14,15], and so on [16-18]. HPLC is a proper method due to its low cost and wide range of application. However, analysis performed on conventional HPLC lacks of sensitivity [11-13]. Capillary electrophoresis is also commonly used in determination of vancomycin, the advantages of the method includes low sample consumption, high separation efficiency, short analysis time, and so on, but the reproducibility of this method is poor [14,15]. Up to now, HPLC-MS/MS methods are the most common used methods for determination of vancomycin [19-22]. The methods were successfully applied into quantify vancomycin in different matrices, but each of them had its limitations. The methods either required a long analysis time [19], lacked of internal standard [19], or had insufficient sensitivity [20-22].

So far, reports of determination of vancomycin using Q-trap MS are seldom, Schmitt et al. [23] once established a Q-trap MS method for determination of vancomycin in rabbit serum, but they lacked studies of matrix effects and stability, which caused the incomplete of the method. In this research, a reliable method based on Q-trap-MS was developed to determine vancomycin; the methodological parameters were verified comprehensively. The proposed method is simple, precise and accurate; it is applicable to determination of vancomycin in multiple samples.

\section{Material and Methods}

\subsection{Chemicals, Reagents and Samples}

Vancomycin and norvancomycin were obtained from Ehrenstorfer (Augsburg, Germany, purity grade $>95.0 \%$ ). Methanol ( $\mathrm{MeOH}, \mathrm{LC} / \mathrm{MS}$ grade), acetonitrile (MeCN, LC/MS grade), and formic acid (98\%) were purchased from Sigma-Aldrich (St. Quentin Fallavier, France). Milli-Q-System (Millipore, Guyancourt, France) was adopted for purifying water. A nylon membrane filter (pore size: $0.22 \mu \mathrm{m}$ ) was obtained from Jinteng Laboratory Equipment Co., Ltd. (Tianjin, China).

\subsection{Apparatus}

The HPLC-Q-trap-MS system consisted of an AB SCIEXQTRAP ${ }^{\circledR} 6500$ mass spectrometer (AB SCIEX LLC. Redwood City, CA, USA) and HPLC chromatographic analysis system (Spark Holland B.V., Holland) with Alias ${ }^{\mathrm{TM}}$ Autosampler, SPH 1240 Gradient Pump. 


\subsection{Preparation of Quality Controls and Standard Solutions}

The standard stock solutions of vancomycin and norvancomycin (IS) were prepared by dissolving accurately weighed standard compound in deionized water at $1.0 \mathrm{mg} / \mathrm{mL}$. Then, the working solutions of vancomycin were diluted serially with deionized water to achieve final concentrations of 10, 20, 50, $100,200,500,1000,2000,5000,10,000$, and 20,000 ng/mL. Ten microliters of the diluted solutions were added to blank serum to obtain final concentrations ranged from 1 to $2000 \mathrm{ng} / \mathrm{mL}$.

The IS working solution was diluted with deionized water to give a final concentration of $100 \mathrm{ng} / \mathrm{mL}$. Quality control (QC) samples were prepared in $100 \mu \mathrm{L}$ of blank serum by adding $10 \mu \mathrm{L}$ of serially diluted solutions of the substance to determine the limit of quantification, as well as $2 \mathrm{ng} / \mathrm{mL}$ (low), $20 \mathrm{ng} / \mathrm{mL}$ (medium), and $400 \mathrm{ng} / \mathrm{mL}$ (high) concentrations. The L, M, and $\mathrm{H}$ of QCs were analyzed at least in duplicate. All solutions were stored at $-20{ }^{\circ} \mathrm{C}$ and brought to room temperature before use.

\subsection{HPLC-Q-Trap-MS Conditions}

The chromatographic separation was performed on an Agilent ZORBAX SB-C $18(4.6 \times 150 \mathrm{~mm}$, $5 \mu \mathrm{m}$ ). The mobile phase consisted of water (containing $0.1 \%$ formic acid, $v / v$ ) and acetonitrile (containing $0.1 \%$ formic acid, $v / v$ ) and the flow rate was set at $0.5 \mathrm{~mL} / \mathrm{min}$. An isocratic elution was performed with $30 \%$ of acetonitrile. The total run time was $8 \mathrm{~min}$. The injection volume was $10 \mu \mathrm{L}$.

The mass spectrometer was operated in the positive ion electrospray mode with curtain gas flow rates of $20 \mathrm{psi}$. The ion spray voltage and the source temperature were set at $5000 \mathrm{~V}$ and $300{ }^{\circ} \mathrm{C}$, respectively. Multiple reaction monitoring (MRM) was adopt for data acquisition. The optimized precursor-to-product ion transitions monitored for vancomycin $[\mathrm{M}+2 \mathrm{H}]^{2+}$ were $m / z 725.8 \rightarrow 144.2$ with declustering potential (DP) $50 \mathrm{~V}$, collision energy (CE) $20.4 \mathrm{~V}$, and $m / z 725.8 \rightarrow 100.1$ with declustering potential (DP) $50 \mathrm{~V}$ and collision energy (CE) $50.4 \mathrm{~V}$, respectively. The optimized precursor-to-product ion transitions monitored for norvancomycin $[\mathrm{M}+\mathrm{H}]^{2+}$ were $\mathrm{m} / z 718.8 \rightarrow$ 144.3 with DP $40 \mathrm{~V}, \mathrm{CE} 19 \mathrm{~V}$ and $m / z 718.8 \rightarrow 99.7$ with DP $40 \mathrm{~V}$ and CE $65 \mathrm{~V}$, respectively.

\subsection{Sample Source and Pretreatment}

Clinical samples were collected at Air Force General Hospital, PLA. Fifty patients with DFIs and 50 nondiabetic patients with pneumonia who had been treated with vancomycin for a suspected or proven Gram-positive infection and met the TDM guidelines for vancomycin were included. Human blank serum was obtained from healthy blood donors not using vancomycin (Air Force General Hospital, PLA.). The study was approved by the hospital ethics committee. Every patient was given a sufficient description of the study and signed an informed consent prior to the study.

The pretreatment followed for all samples was $10 \mu \mathrm{L}$ of the IS was added to $20 \mu \mathrm{L}$ of the standard and unknown serum samples and mixed vigorously for $20 \mathrm{~s}$. Five-hundred microliters of acetonitrile was added, vortexed for $1 \mathrm{~min}$, and centrifuged for $6 \mathrm{~min}$ at 12,000 rpm. After transferring the supernatant to a fresh centrifuge tube, it was evaporated to dryness under a stream of nitrogen at room temperature. Two-hundred microliters of mobile phase was added to the resulting residue and vortexed for $1 \mathrm{~min} ; 100 \mu \mathrm{L}$ was analyzed.

\subsection{Method Validation}

\subsubsection{Specificity}

The specificity of the method was evaluated by comparing the chromatography of blank serum samples with that of blank serum spiked with vancomycin and/or norvancomycin (IS) and serum samples of patients treated with vancomycin. 


\subsubsection{Linearity and Sensitivity}

The calibration curve for vancomycin was validated with a series of standard samples in the range of 1 to $2000 \mathrm{ng} / \mathrm{mL}$ in serum. The linearity of the calibration curves was generated by plotting the ratio of the analyte to the IS signal versus the analyte concentration and fitted by a weighted linear least-squares linear regression with a weighting factor of $1 / y$, where $y$ is the peak area ratio of vancomycin versus IS. The calibration curve was obtained by analyzing three replicates of the QC samples

Sensitivity of the method was evaluated in terms of LOQ which was determined based on two criteria as follows, (1) the analyte response at the LOQ be at least 10 times the response compared to the blank response and (2) the analyte peak must be identifiable, discrete, and reproducible with an accuracy (relative error) and precision (relative standard deviation, RSD) within 15\%.

\subsubsection{Precision, Accuracy and Matrix Effect}

The intraday accuracy and precision were obtained by analyzing seven replicates of the QC samples at three concentrations $(400,20$, and $2 \mathrm{ng} / \mathrm{mL}$ ) in a day, while the interday accuracy and precision were conducted by determining the replicates on three separate days. Freshly prepared calibration standards were used to measure the concentration of each QC sample. The relative standard deviation (RSD) of the replicates was used to represent the precision. The matrix effect was determined by dividing the slopes of calibration curves of vancomycin in blood matrix and mobile phase.

The accuracy was determined based on the following criteria. (1) The mean value should not exceed $15 \%$ of the nominal concentration and (2) for the LOQ, it should not exceed $20 \%$. Similarity, the RSD of precision for each concentration level should not be deviated by more than $\pm 15 \%$, while for the LOQ, it should not exceed $20 \%$.

\subsubsection{Recovery}

The recovery of vancomycin was measured on QC samples at three concentrations $(400,20$, and $2 \mathrm{ng} / \mathrm{mL}$ ) in five replicates. The extraction recovery was assessed by comparing the peak area responses for the extracted samples of $Q C$ with those of the extracts of blank serum samples added with the same concentration of IS.

\subsubsection{Stability}

In order to evaluate the stability of vancomycin in serum, four studies (bench-top stability, freeze-thaw stability, long-term stability, and autosampler stability) were employed. For the bench-top stability during handing, QC samples were prepared and kept room temperature $\left(25^{\circ} \mathrm{C}\right)$ for $6 \mathrm{~h}$. Freeze $\left(-80{ }^{\circ} \mathrm{C}\right)$-thaw (room temperature) stability of the analytes was tested with three free-thaw cycles. For long-term stability, the QC samples were stored at $-80^{\circ} \mathrm{C}$ for 30 days. Stability of sample in autosampler was determined by analyzing the targets after kept in an autosampler at room temperature for $12 \mathrm{~h}$.

\section{Results}

\subsection{HPLC-MS Instrument Method Development}

Q-Trap-MS is widely used due to its advantages high sensitivity, good repeatability, and wide dynamic range [24]. Vancomycin is a polar compound [25], so a positive ESI mode was employed.

Step 1: The appropriate precursor ion to be fragmented should be confirmed first. Vancomycin can be easily protonated to form doubly-charged protonated molecular ions in the positive ESI mode since it possesses nitrogen-containing functional groups [13]. In the chosen scan mode, as seen in Figure 2, the target was identified according to its mass in the form of a doubly-charged ion. 


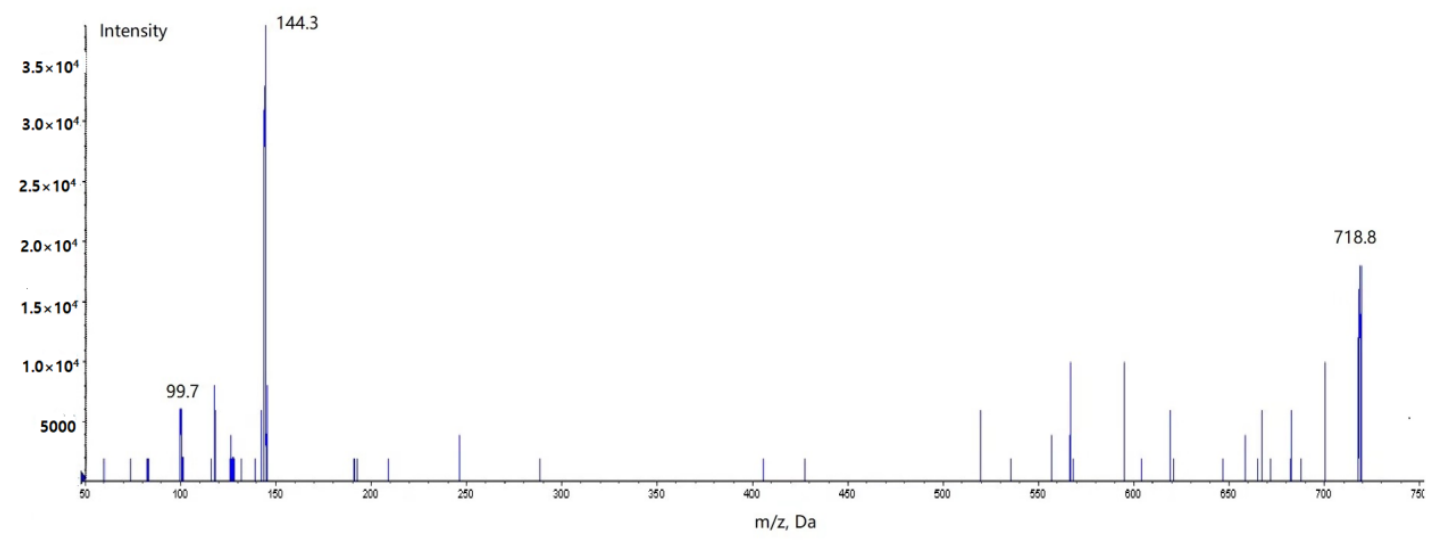

(a)

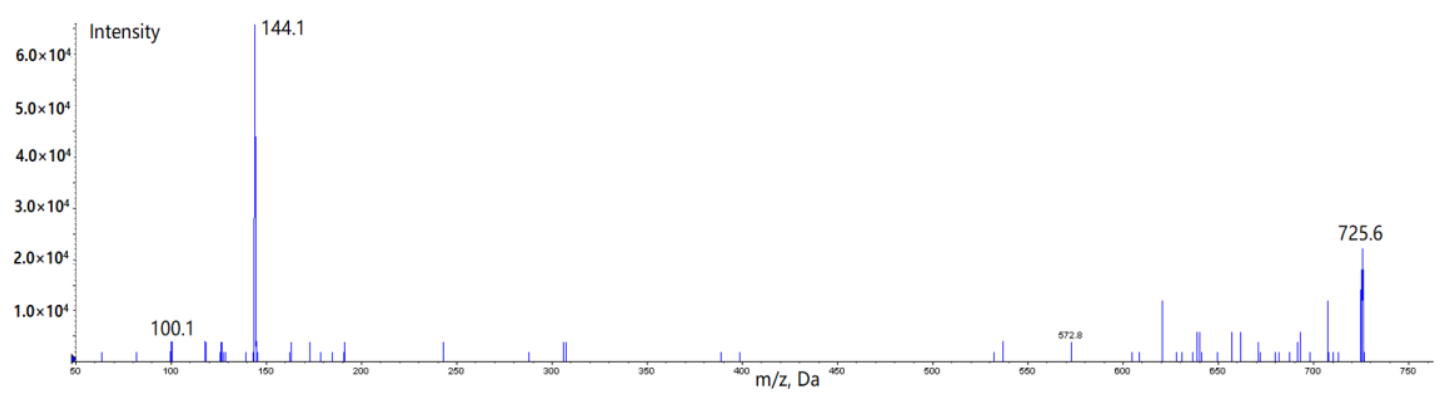

(b)

Figure 2. Product ion mass spectra of $[\mathrm{M}+\mathrm{H}]^{2+}$ for $(\mathbf{a})$ vancomycin $(718.8 \rightarrow 144.3,99.7)$ and (b) norvancomycin $(725.6 \rightarrow 144.1,100.1)$.

Step 2: The product ions scan mode was used to select suitable fragment ions of the precursor ion. More than three fragment ions for the target were usually tested and among them, two more sensitive ions are chosen for the final mode (See in Figure 2).

Step 3: Both CE and DP should be optimized since are critical parameters which can affect the sensitivity of the target. The optimizing values were set from 0 to $180 \mathrm{eV}$ during the optimizing process of CE and DP in MRM mode. The value of the highest abundance was chosen for the targets.

\subsection{Sample Extraction Method Development}

\subsubsection{Optimization of the Pretreatment Method}

In this research, we investigated the matrix effect first, the matrix effect was examined by calculating the percentage $(\mathrm{C} \%)$ of signal enhancement or suppression, according to Equation (1): $\mathrm{C} \%=(1-\mathrm{Ss} / \mathrm{Sm}) \times 100$, where Ss is the slope of matrix-matched calibration curve and $\mathrm{Sm}$ is the slope of standard solution calibration curve [26]. In our work, $\mathrm{C} \%< \pm 15 \%$ is acceptable. The values of $\mathrm{C} \%$ for vancomycin and norvancomycin were $-6.8 \%$ and $5.3 \%$, respectively, which means no obvious matrix effect was observed. Thus, serum samples were directly extracted with acetonitrile.

\subsubsection{Effects of Different Conditions on the Recovery}

Extraction solution and extraction time could greatly affect the extraction efficiency. To achieve the best extraction efficiency, these parameters were optimized. Results showed that acetonitrile has the highest recoveries (87.2-102.3\%) compared to n-hexane, methanol, and ethy lacetate. The extraction time for the highest recovery in acetonitrile was $6 \mathrm{~min}$ at $25^{\circ} \mathrm{C}$. 


\subsection{Method Validation}

The method validation was carried out in accordance with Food and Drug Administration (FDA) regulations for the validation of bioanalytical methods [27].

\subsubsection{Specificity}

The representative chromatogram of the blank serum (a), vancomycin standard in deionized water (b), vancomycin standard in serum (c) were shown in Figure 3. It can be seen that there was no significant interference with the vancomycin at its retention times in blank serum.

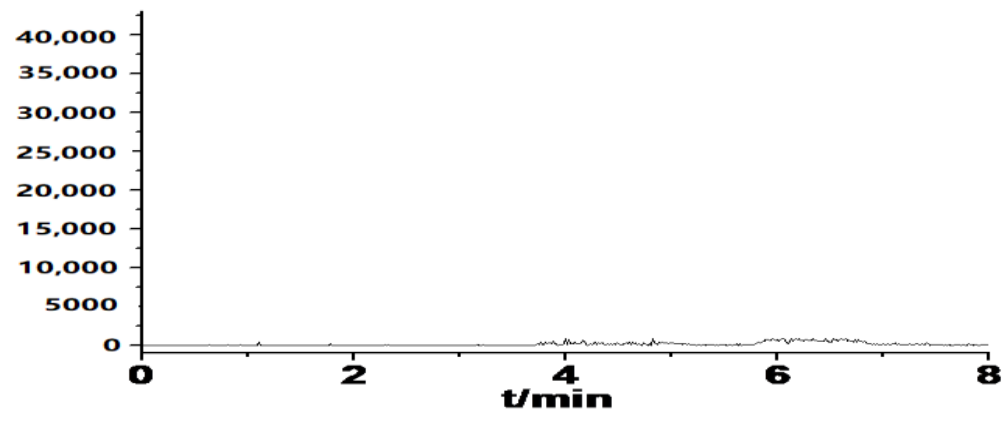

(a)

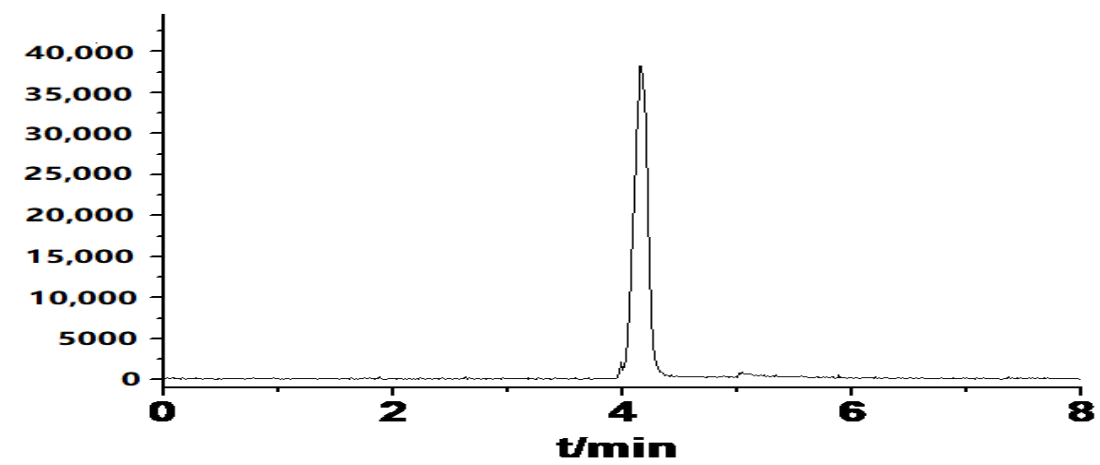

(b)

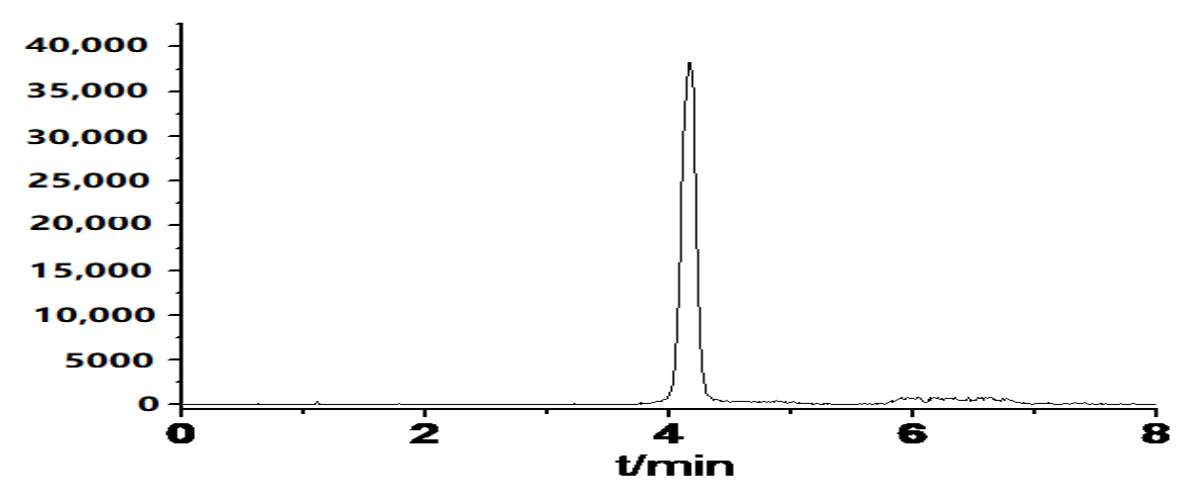

(c)

Figure 3. Cont. 


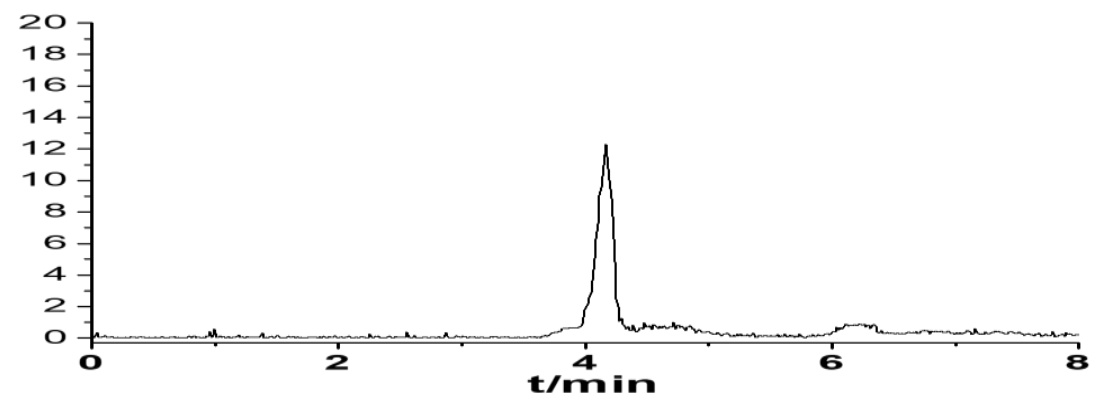

(d)

Figure 3. Typical chromatograms of (a) blank serum, (b) vancomycin standard in deionized water $(500 \mathrm{ng} / \mathrm{mL}),(\mathbf{c})$ vancomycin standard in serum (patients after treated with vancomycin), (d) blank sample spiked with vancomycin $(1 \mathrm{ng} / \mathrm{mL})$.

\subsubsection{Calibration and LOQ}

Eleven different concentrations from 1 to $2000 \mathrm{ng} / \mathrm{mL}$ were analyzed for the calibration standards. The typical linear regression equation of the calibration curve was $y=597 x+5.6 \times 10^{3}$ for vancomycin and it exhibited a good linearity $\left(R^{2}=0.9999\right)$.

The LOQ of vancomycin was $1 \mathrm{ng} / \mathrm{mL}$, which was significantly lower than the values reported in other methods [11,12,20-22], and it was significantly lower than the minimum effective concentration of vancomycin in serum.

\subsubsection{Precision and Accuracy}

Table 1 showed the intra- and interday accuracy and precision using QC samples at 400, 20, and $2 \mathrm{ng} / \mathrm{mL}$ (representing high, medium, and low concentrations, respectively). It could be seen that the intra- and interday precision ranged from 3.21 to $6.67 \%$ and 4.11 to $7.14 \%$, respectively, representing which was within the acceptance limit of $15 \%$.

Table 1. Intra and interday precision and accuracy of vancomycin in serum.

\begin{tabular}{ccccccc}
\hline \multirow{2}{*}{$\begin{array}{c}\text { Concentration } \\
(\mathbf{n g} / \mathbf{m L})\end{array}$} & $\begin{array}{c}\text { Measured } \\
\text { Conc (ng/mL) }\end{array}$ & $\begin{array}{c}\text { Precision, } \\
\text { RSD (\%) }\end{array}$ & $\begin{array}{c}\text { Accuracy } \\
\mathbf{( \% )}\end{array}$ & $\begin{array}{c}\text { Measured } \\
\text { Conc (ng/mL) }\end{array}$ & $\begin{array}{c}\text { Precision } \\
\text { RSD (\%) }\end{array}$ & $\begin{array}{c}\text { Accuracy } \\
\mathbf{( \% )}\end{array}$ \\
\hline 400 & $396.66 \pm 22.17$ & 3.21 & 99.17 & $394.38 \pm 23.75$ & 4.11 & 98.60 \\
20 & $20.98 \pm 1.52$ & 5.17 & 104.90 & $21.14 \pm 1.91$ & 5.86 & 105.70 \\
2 & $2.10 \pm 0.19$ & 6.67 & 105.00 & $1.99 \pm 0.18$ & 7.14 & 99.50 \\
\hline
\end{tabular}

\subsubsection{Extraction recovery}

As shown in Table 2, the results indicated that the method showed high recovery in serum. The recoveries were over $85 \%$, indicating the suitability of the proposed method for the determination of vancomycin. The precision was satisfactory with a RSDs below $4 \%$ for spiked samples.

Table 2. Extraction recovery of vancomycin in serum.

\begin{tabular}{cccc}
\hline \multirow{2}{*}{ Analyte } & \multirow{2}{*}{ Concentration $(\mathbf{n g} / \mathbf{m L})$} & \multicolumn{2}{c}{ Extraction Recovery (\%) } \\
\cline { 3 - 4 } & & Mean \pm SD & RSD \\
\hline \multirow{3}{*}{ Vancomycin } & 400 & $99.72 \pm 2.23$ & 1.26 \\
& 20 & $94.94 \pm 3.88$ & 1.59 \\
& 2 & $92.51 \pm 4.18$ & 3.67 \\
\hline
\end{tabular}




\subsubsection{Stability}

Stability of vancomycin in serum was evaluated at three different concentrations. As shown in Table 3 , vancomycin was stable in serum at $4{ }^{\circ} \mathrm{C}$ and $25^{\circ} \mathrm{C}$ for $24 \mathrm{~h}$, after three freezing and thawing cycles and stored at $-80^{\circ} \mathrm{C}$ for 30 days.

Table 3. Stability of vancomycin in serum under various storage conditions.

\begin{tabular}{cccc}
\hline Storage Condition & Concentration $(\mathbf{n g} / \mathrm{L})$ & Mean \pm SD (ng/L) & RSD \% \\
\hline \multirow{2}{*}{ Autosampler $\left(4^{\circ} \mathrm{C}\right)$ temperature for $24 \mathrm{~h}$} & 2 & $2.20 \pm 0.21$ & 8.76 \\
& 20 & $21.67 \pm 1.92$ & 8.13 \\
Room temperature $\left(25{ }^{\circ} \mathrm{C}\right)$ for $24 \mathrm{~h}$ & 400 & $408.16 \pm 7.88$ & 2.19 \\
\hline & 2 & $2.24 \pm 0.25$ & 3.33 \\
$-80^{\circ} \mathrm{C}$ for 30 days & 20 & $22.14 \pm 2.24$ & 6.51 \\
& 400 & $406.12 \pm 6.92$ & 2.26 \\
\hline & 2 & $2.29 \pm 0.24$ & 8.91 \\
Freezing and thawing cycles & 20 & $21.01 \pm 1.73$ & 8.77 \\
& 400 & $420.11 \pm 7.95$ & 2.11 \\
\hline
\end{tabular}

\subsection{Clinical Application}

\subsubsection{Patients and Methods}

Fifty diabetes mellitus type 2 patients with known or suspected Gram-positive DFI (Wagner score grade 3/4, equivalent to Texas classification of at least B3), and 50 nondiabetic patients with pneumonia requiring antibiotic therapy from 2014 to 2016 were included. A total of 100 trough serum samples of vancomycin were analyzed with this method. Steady-state serum vancomycin concentration for a dosing regimen of $1 \mathrm{~g} \mathrm{q} 12 \mathrm{~h}$ were compared between the two groups. Blood collection should be started around $48 \mathrm{~h}$ after the administration of vancomycin. The concentration of vancomycin should be maintained between 10 to $20 \mathrm{mg} / \mathrm{L}$ in adult patients based on a guideline of the therapeutic drug monitoring of vancomycin by Chinese Pharmacological Society [28]. The estimated $\mathrm{Cl}_{\mathrm{Cr}}$ was calculated from serum creatinine using the Cockcroft-Gault formula [29]. $\mathrm{CrCl}=(140$-age in years $) \times$ body weight in $\mathrm{kg} /($ serum creatinine in $\mu \mathrm{mol} / \mathrm{mL} \times 815) \times 0.85$ for females). Statistical analysis was performed by SPSS 25.0.

\subsubsection{Results}

Dose and dosage interval for all patients included in this experiment were the same (1g q12h). As listed in Table 4, there were more patients that achieved target trough concentration of vancomycin among nondiabetic group compared with DFI group $(40(80.0 \%)$ vs. $18(36.0 \%), p=0.020)$. The trough concentration of vancomycin in diabetic foot patients was significantly lower than that of nondiabetic patients $(8.20 \pm 2.83 \mu \mathrm{g} / \mathrm{mL}$ (range: $4.80-14.2 \mu \mathrm{g} / \mathrm{mL}$ ) vs. $15.80 \pm 5.43 \mu \mathrm{g} / \mathrm{mL}$ (range: $8.60-19.5 \mu \mathrm{g} / \mathrm{mL}), p=0.004)$. $\mathrm{CrCl}$ in diabetic foot patients was higher than that in nondiabetic patients $(126.14 \pm 42.36 \mathrm{~mL} / \mathrm{min}$ vs. $105.76 \pm 38.66 \mathrm{~mL} / \mathrm{min}, p=0.005)$, which may be an important cause of the significant difference in serum concentration of vancomycin in the two groups. 
Table 4. Comparison of DFI group and nondiabetic group.

\begin{tabular}{lcccc}
\hline & $\begin{array}{c}\text { DFI Group } \\
(\boldsymbol{n}=\mathbf{5 0 )}\end{array}$ & $\begin{array}{c}\text { Nondiabetic } \\
\text { Group }(\boldsymbol{n}=\mathbf{5 0})\end{array}$ & $\chi^{2 / \mathbf{t}}$ & $\boldsymbol{p}$ \\
\hline Samples of achieving target trough concentration & $18(36.0 \%)$ & $40(80.0 \%)$ & 5.386 & 0.020 \\
\hline Trough Concentration of vancomycin $(\mu \mathrm{g} / \mathrm{mL})$ & $8.20 \pm 2.83$ & $15.8 \pm 5.43$ & 3.781 & 0.004 \\
\hline $\mathrm{Cl}_{\mathrm{Cr}}(\mathrm{mL} / \mathrm{min})$ & $126.14 \pm 42.36$ & $105.76 \pm 38.66$ & 2.891 & 0.005 \\
\hline
\end{tabular}

\section{Discussion}

In recent days, a phenomenon which called 'augmented renal clearance' (ARC) was often mentioned by the researchers. ARC mainly referred to the enhancement of elimination of circulating solutes and exhibited as a hypermetabolic status. The presence of hypermetabolism in patients with ARC, which results in increased renal blood flow and the rate of glomerular filtration [30-33], may lead to the treatment failure of antibiotics [34-37]. Under normal conditions, target tissue and blood concentration can be obtained using the standard dosage of vancomycin, but in ARC patients, drug concentration in vivo was usually abnormal.

Our results showed that the trough concentration of DFI patients was significantly lower than that of patients without diabetes. Previous study showed that the plasma concentration of vancomycin in diabetic patients and nondiabetic patients were similar [8]. However, only six diabetic patients and six nondiabetic patients were enrolled, and there was no significantly difference in the average creatinine clearance of the two groups. But in our study, the $\mathrm{Cl}_{\mathrm{Cr}}$ of DFI patients were significantly higher than that of nondiabetic foot infections, with a mean value of $126.14 \mathrm{~mL} / \mathrm{min}$.

Although the normal limits of $\mathrm{Cl}_{\mathrm{Cr}}$ were defined as $130 \mathrm{~mL} / \mathrm{min} / 1.73 \mathrm{~m}^{2}$ for male and $120 \mathrm{~mL} / \mathrm{min} / 1.73 \mathrm{~m}^{2}$ for female, respectively [38], $\mathrm{Cl}_{\mathrm{Cr}}$ values greater than $120-130 \mathrm{~mL} / \mathrm{min} / 1.73 \mathrm{~m}^{2}$ were defined as increased renal clearance, regardless of gender [38,39]. Another study recommended that $\mathrm{Cl}_{\mathrm{Cr}}>150 \mathrm{~mL} / \mathrm{min} / 1.73 \mathrm{~m}^{2}$ and $>120 \mathrm{~mL} / \mathrm{min} / 1.73 \mathrm{~m}^{2}$ were used for definition of hyperfiltration for young and elderly adults, respectively [40]. In the study, we chose $\mathrm{Cl}_{\mathrm{Cr}}>120 \mathrm{~mL} / \mathrm{min} / 1.73 \mathrm{~m}^{2}$ as the critical value of hyperfiltration state, considering that the patients in our study were mainly elderly, with an average age of 61 years. Diabetics in our study are all DFIs patients; most of them had poor glycemic control, complicated with diabetic nephropathy stage I, which appears glomerular hyperfiltration. It means that diabetic patients in our study have high level of $\mathrm{Cl}_{\mathrm{Cr}}$, which can affect the clearance of hydrophilia antibiotics such as vancomycin.

Vancomycin is a typical hydrophilic antibiotic excreted mainly by kidney. Its clearance is closely related to $\mathrm{Cl}_{\mathrm{Cr}}$, showing time-dependent activity [41-44]. We have known that the kidney could become enlarged and the glomerular filtration rate becomes abnormal in the early stages of diabetes [30]. Many studies have shown that the kidneys show a persistent increase in glomerular filtration rate in diabetic patients, ranged from 20 to $30 \%$, and in some untreated diabetic patients may be as high as 30 to $40 \%$ [45]. A lot of studies have pointed out that primary abnormalities in vascular control can increase renal blood flow and vasodilate the renal vessels [36-41]. Gruden et al. [46] reported an improvement between 25 to $50 \%$ of GFR in more than $70 \%$ patients with type 1 diabetes at the early stages of diagnosis or in the early years of the disease and before the onset of proteinuria, while in type 2 diabetes mellitus patients, high glomerular filtration was found in 50\% patients in the early years of the disease [47-49]. Therefore, the clearance of drugs excreted through the kidney, such as vancomycin, was elevated by the augmented glomerular filtration and the increased renal blood flow; it was the most likely risk factor for unsatisfactory vancomycin trough concentration. In some recent studies, the use of vancomycin loaded doses or continuous infusion may be strategies to avoid the phenomenon [41]. In the future, more DFI patients should be involved to be studied on vancomycin serum concentration compared with nondiabetics to insure whether high glomerular filtration is an important risk factor of failure of hydrophilic antibiotic on anti-infective therapy of DFIs. 


\section{Conclusions}

In this study, a precise and sensitive quantitative method was developed and validated for analysis of vancomycin in serum by HPLC-Q-Trap-MS. The method exhibited excellent precision, recovery and curve linearity for the analyte. The method can be successfully applied to analysis of the target. The results indicated that HPLC-Q-Trap-MS could serve as a highly interesting analytical alternative for bioanalysis.

Author Contributions: Conceived and designed the article: M.L., G.-H.L., and Z.-H.Y. All authors read and approved the final manuscript.

Funding: This work was supported by the CAMS Innovation Fund for Medical Sciences (CIFMS) (No. 2016-I2M-1-001).

Conflicts of Interest: The authors declare no conflict of interest.

\section{References}

1. Citron, D.M.; Goldstein, E.J; Merriam, C.V.; Lipsky, B.A.; Abramson, M.A. Bacteriology of moderate-to-severe diabetic foot infections and in vitro activity of antimicrobial agents. J. Clin. Microbiol. 2007, 45, 2819-2828. [CrossRef] [PubMed]

2. Lipsky, B.A.; Aragón-Sánchez, J.; Diggle, M.; Embil, J.; Kono, S.; Lavery, L. International Working Group on the Diabetic Foot (IWGDF). IWGDF guidance on the diagnosis and management of foot infections in persons with diabetes. Diabetes-Metab. Res. 2016, 32, 45-74. [CrossRef] [PubMed]

3. Lipsky, B.A.; Berendt, A.R.; Deery, H.G.; Embil, J.M.; Joseph, W.S.; Karchmer, A.W.; LeFrock, J.L.; Lew, D.P.; Mader, J.T.; Norden, C.; et al. Diagnosis and treatment of diabetic foot infections. Clin. Infect. Dis. 2004, 39, 885-910. [CrossRef] [PubMed]

4. Lipsky, B.A. Empirical therapy for diabetic foot infections: Are there clinical clues to guide antibiotic selection? Clin. Microbiol. Infect. 2007, 13, 351-353. [CrossRef] [PubMed]

5. Courtney, P.M.; Melnic, C.M.; Zimmer, Z.; Anari, J.; Lee, G.C. Addition of vancomycin to cefazolin prophylaxis is associated with acute kidney injury after primary joint arthroplasty. Clin. Orthop. Relat. $R$. 2015, 473, 2197-2203. [CrossRef] [PubMed]

6. Davis, J.S.; Sud, A.; O'Sullivan, M.V.; Robinson, J.O.; Ferguson, P.E.; Foo, H.; Kirby, A. Combination of vancomycin and $\beta$-lactam therapy for methicillin-resistant Staphylococcus aureus bacteremia: A pilot multicenter randomized controlled trial. Clin. Infect. Dis. 2015, 62, 173-180. [CrossRef] [PubMed]

7. Wiskirchen, D.E.; Shepard, A.; Kuti, J.L.; Nicolau, D.P. Determination of tissue penetration and pharmacokinetics of linezolid in patients with diabetic foot infections using in vivo microdialysis. Antimicrob. Agents Chemother. 2011. [CrossRef] [PubMed]

8. Skhirtladze, K.; Hutschala, D.; Fleck, T.; Thalhammer, F.; Ehrlich, M.; Vukovich, T.; Tschernko, E.M. Impaired target site penetration of vancomycin in diabetic patients following cardiac surgery. Antimicrob. Agents Chemother. 2006, 50, 1372-1375. [CrossRef] [PubMed]

9. Payne, C.J.; Thomson, A.H.; Stearns, A.T.; Watson, D.G.; Zhang, T.; Kingsmore, D.B.; Binning, A.S. Pharmacokinetics and tissue penetration of vancomycin continuous infusion as prophylaxis for vascular surgery. J. Antimicrob. Chemother. 2011, 66, 2624-2627. [CrossRef] [PubMed]

10. Housman, S.T.; Bhalodi, A.A.; Shepard, A.; Nugent, J.; Nicolau, D.P. Vancomycin tissue pharmacokinetics in patients with lower-limb infections via in vivo microdialysis. J. Am. Podiat. Med. ASSN 2015, 105, 381-388. [CrossRef] [PubMed]

11. Usman, M.; Hempel, G. Development and validation of an HPLC method for the determination of vancomycin in human plasma and its comparison with an immunoassay (PETINIA). SpringerPlus 2016, 5, 124. [CrossRef] [PubMed]

12. Sheng, Y.; Zhou, B. High-throughput determination of vancomycin in human plasma by a cost-effective system of two-dimensional liquid chromatography. J. Chromatogr. A 2017, 1499, 48-56. [CrossRef] [PubMed]

13. Barco, S.; Castagnola, E.; Gennai, I.; Barbagallo, L.; Loy, A.; Tripodi, G.; Cangemi, G. Ultra high performance liquid chromatography-tandem mass spectrometry vs. commercial immunoassay for determination of vancomycin plasma concentration in children. Possible implications for everyday clinical practice. J. Chemother. 2016, 28, 395-402. [CrossRef] [PubMed] 
14. Wang, J.; Cao, Y.; Wu, S.; Wang, S.; Zhao, X.; Zhou, T.; Fan, G. Determination of Vancomycin in Human Serum by Cyclodextrin-Micellar Electrokinetic Capillary Chromatography (CD-MEKC) and Application for PDAP Patients. Molecules 2017, 22, 538. [CrossRef] [PubMed]

15. Chong, K.C.; Thang, L.Y.; Quirino, J.P.; See, H.H. Monitoring of vancomycin in human plasma via portable microchip electrophoresis with contactless conductivity detector and multi-stacking strategy. J. Chromatogr. A 2017, 1485, 142-146. [CrossRef] [PubMed]

16. Khataee, A.; Lotfi, R.; Hasanzadeh, A. A novel permanganate-morin-CdS quantum dots flow injection chemiluminescence system for sensitive determination of vancomycin. RSC Adv. 2015, 5, 82645-82653. [CrossRef]

17. Odekerken, J.C.; Logister, D.M.; Assabre, L.; Arts, J.J.; Walenkamp, G.H.; Welting, T.J. ELISA-based detection of gentamicin and vancomycin in protein-containing samples. SpringerPlus 2015, 4, 614. [CrossRef] [PubMed]

18. Khataee, A.R.; Hasanzadeh, A.; Iranifam, M.; Fathinia, M.; Hanifehpour, Y.; Joo, S.W. CuO nanosheets-enhanced flow-injection chemiluminescence system for determination of vancomycin in water, pharmaceutical and human serum. Spectrochim. Acta Part A 2014, 122, 737-743. [CrossRef] [PubMed]

19. König, K.; Kobold, U.; Fink, G.; Leinenbach, A.; Dülffer, T.; Thiele, R.; Vogeser, M. Quantification of vancomycin in human serum by LC-MS/MS. Clin. Chem. Lab. Med. 2013, 51, 1761-1769. [CrossRef] [PubMed]

20. Parker, S.L.; Guerra Valero, Y.C.; Ordóñez Mejia, J.L.; Roger, C.; Lipman, J.; Roberts, J.A.; Wallis, S.C. An LC-MS/MS method to determine vancomycin in plasma (total and unbound), urine and renal replacement therapy effluent. Bioanalysis 2017, 9, 911-924. [CrossRef] [PubMed]

21. Zhang, M.; Moore, G.A.; Young, S.W. Determination of vancomycin in human plasma, bone and fat by liquid chromatography/tandem mass spectrometry. J Anal. Bioanal. Tech. 2014, 5. [CrossRef]

22. Oyaert, M.; Peersman, N.; Kieffer, D.; Deiteren, K.; Smits, A.; Allegaert, K.; Pauwels, S. Novel LC-MS/MS method for plasma vancomycin: Comparison with immunoassays and clinical impact. Clin. Chim. Acta 2015, 441, 63-70. [CrossRef] [PubMed]

23. Schmitt, V.; Szeitz, A.; Klassen, T.L.; Häfeli, U.O. An Ultra-High Performance Liquid ChromatographyTandem Mass Spectrometry Method for the Quantification of Vancomycin Requiring Only $2 \mu \mathrm{L}$ of Rabbit Serum. Am. J. Anal. Chem. 2017, 8, 553. [CrossRef]

24. Lu, Z.; Wang, Q.; Wang, M.; Fu, S.; Zhang, Q.; Zhang, Z.; Zhao, H.; Liu, Y.; Huang, Z.; Xie, Z.; et al. Using UHPLC Q-Trap/MS as a complementary technique to in-depth mine UPLC Q-TOF/MS data for identifying modified nucleosides in urine. J. Chromatogr. B 2017, 1051, 108-117. [CrossRef] [PubMed]

25. Kim, K.Y.; Cho, S.H.; Song, Y.H.; Nam, M.S.; Kim, C.W. Direct injection LC-MS/MS method for the determination of teicoplanin in human plasma. J. Chromatogr. B 2016, 1008, 125-131. [CrossRef] [PubMed]

26. Zhou, W.E.; Zhang, Y.; Li, Y.; Ling, Y.; Li, H.N.; Li, S.H.; Jiang, S.J.; Ren, Z.Q.; Huang, Z.Q.; Zhang, F. Determination of gardenia yellow colorants in soft drink, pastry, instant noodles with ultrasound-assisted extraction by high performance liquid chromatography-electrospray ionization tandem mass spectrum. J. Chromatogr. A 2016, 1446, 59-69. [CrossRef] [PubMed]

27. Park, M.H.; Byeon, J.J.; Shin, S.H.; Kim, N.; Park, Y.; Lee, B.I.; Choi, J.; Shin, Y.G. Rapid and simultaneous quantification of a mixture of biopharmaceuticals by a liquid chromatography/quadrupole time-of-flight mass spectrometric method in rat plasma following cassette-dosing. Rapid Commun. Mass Spectrom. 2018, 32, 889-896. [CrossRef] [PubMed]

28. Ye, Z.K.; Chen, Y.L.; Chen, K.; Zhang, X.L.; Du, G.H.; He, B.; Li, D.K.; Liu, Y.N.; Yang, K.H.; Zhang, Y.Y.; et al. Therapeutic drug monitoring of vancomycin: A guideline of the Division of Therapeutic Drug Monitoring, Chinese Pharmacological Society. J. Antimicrob. Chemother. 2016, 71, 3020-3025. [CrossRef] [PubMed]

29. Kellum, J.A.; Sileanu, F.E.; Murugan, R.; Lucko, N.; Shaw, A.D.; Clermont, G. Classifying AKI by urine output versus serum creatinine level. J. Am. Soc. Nephrol. 2015, 26, 2231-2238. [CrossRef] [PubMed]

30. Athyros, V.G.; Katsiki, N.; Karagiannis, A.; Mikhailidis, D.P. Statins can improve proteinuria and glomerular filtration rate loss in chronic kidney disease patients, further reducing cardiovascular risk. Fact or fiction? Expert Opin. Pharmacother. 2015, 16, 1449-1461. [CrossRef] [PubMed]

31. Udy, A.A.; Putt, M.T.; Boots, R.J.; Lipman, J. ARC-augmented renal clearance. Curr. Pharm. Biotechnol. 2011, 12, 2020-2029. [CrossRef] [PubMed]

32. Baptista, J.P.; Sousa, E.; Martins, P.J.; Pimentel, J.M. Augmented renal clearance in septic patients and implications for vancomycin optimisation. Int. J. Antimicrob. Agents 2012, 39, 420-423. [CrossRef] [PubMed] 
33. Minkutè, R.; Briedis, V.; Steponavičiūtè, R.; Vitkauskienè, A.; Mačiulaitis, R. Augmented renal clearance-an evolving risk factor to consider during the treatment with vancomycin. J. Clin. Pharm. Ther. 2013, 38, $462-467$. [CrossRef] [PubMed]

34. Udy, A.A.; Varghese, J.M.; Altukroni, M.; Briscoe, S.; McWhinney, B.C.; Ungerer, J.P.; Roberts, J.A. Subtherapeutic initial $\beta$-lactam concentrations in select critically ill patients. Chest 2012, 142, 30-39. [CrossRef] [PubMed]

35. Udy, A.A.; Roberts, J.A.; Lipman, J. Implications of augmented renal clearance in critically ill patients. Nat. Rev. Nephrol. 2011, 7, 539. [CrossRef] [PubMed]

36. Deresinski, S.; Rybak, M.; Lomaestro, B.; Rotschafer, J.C. (Eds.) Therapeutic monitoring of vancomycin in adult patients: A consensus review of the American Society of Health-System Pharmacists, the Infectious Diseases Society of America, and the Society of Infectious Diseases Pharmacists. Clin. Infect. Dis. 2016, $63,3-4$.

37. Kullar, R.; Davis, S.L.; Levine, D.P.; Rybak, M.J. Impact of vancomycin exposure on outcomes in patients with methicillin-resistant Staphylococcus aureus bacteremia: Support for consensus guidelines suggested targets. Clin. Infect. Dis. 2011, 52, 975-981. [CrossRef] [PubMed]

38. Claus, B.O.; Hoste, E.A.; Colpaert, K.; Robays, H.; Decruyenaere, J.; De Waele, J.J. Augmented renal clearance is a common finding with worse clinical outcome in critically ill patients receiving antimicrobial therapy. J. Crit. Care 2013, 28, 695-700. [CrossRef] [PubMed]

39. Levey, A.S.; Becker, C.; Inker, L.A. Glomerular filtration rate and albuminuria for detection and staging of acute and chronic kidney disease in adults: A systematic review. JAMA 2015, 313, 837-846. [CrossRef] [PubMed]

40. Melsom, T.; Schei, J.; Stefansson, V.T.N.; Solbu, M.D.; Jenssen, T.G.; Mathisen, U.D.; Eriksen, B.O. Prediabetes and risk of glomerular hyperfiltration and albuminuria in the general nondiabetic population: A prospective cohort study. Am. J. Kidney Dis. 2016, 67, 841-850. [CrossRef] [PubMed]

41. Mahmoud, S.; Shen, C. Augmented renal clearance in critical illness: an important consideration in drug dosing. Pharmaceutics 2017, 9, 36. [CrossRef] [PubMed]

42. Cachat, F.; Combescure, C.; Cauderay, M.; Girardin, E.; Chehade, H. A systematic review of glomerular hyperfiltration assessment and definition in the medical literature. Clin. J. Am. Soc. Nephrol. 2015. [CrossRef] [PubMed]

43. Spadaro, S.; Berselli, A.; Fogagnolo, A.; Capuzzo, M.; Ragazzi, R.; Marangoni, E.; Volta, C.A. Evaluation of a protocol for vancomycin administration in critically patients with and without kidney dysfunction. BMC Anesthesiol. 2015, 15, 95. [CrossRef] [PubMed]

44. Kees, M.G.; Hilpert, J.W.; Gnewuch, C.; Kees, F.; Voegeler, S. Clearance of vancomycin during continuous infusion in Intensive Care Unit patients: Correlation with measured and estimated creatinine clearance and serum cystatin C. Int. J. Antimicrob. Agents 2010, 36, 545-548. [CrossRef] [PubMed]

45. Roberts, J.A.; Paul, S.K.; Akova, M.; Bassetti, M.; De Waele, J.J.; Dimopoulos, G.; Rello, J. DALI: Defining antibiotic levels in intensive care unit patients: Are current $\beta$-lactam antibiotic doses sufficient for critically ill patients? Clin. Infect. Dis. 2014, 58, 1072-1083. [CrossRef] [PubMed]

46. Gruden, G.; Barutta, F.; Kunos, G.; Pacher, P. Role of the endocannabinoid system in diabetes and diabetic complications. Br. J. Pharmacol. 2016, 173, 1116-1127. [CrossRef] [PubMed]

47. Hallow, M.; Vallon, V. Mathematical Model-based Analysis of the Acute and Chronic Mechanisms of Diabetic Hyperfiltration. Faseb J. 2016, 30, 740-746.

48. Levine, D.Z. Can rodent models of diabetic kidney disease clarify the significance of early hyperfiltration? Recognizing clinical and experimental uncertainties. Clin. Sci. 2008, 114, 109-118. [CrossRef] [PubMed]

49. Pavkov, M.E.; Nelson, R.G.; Knowler, W.C.; Cheng, Y.; Krolewski, A.S.; Niewczas, M.A. Elevation of circulating TNF receptors 1 and 2 increases the risk of end-stage renal disease in American Indians with type 2 diabetes. Kidney Int. 2015, 87, 812-819. [CrossRef] [PubMed]

Sample Availability: Samples of the compounds are not available from the authors. 